\title{
Test of improvement of the soymilk quality
}

\author{
${ }^{* 1}$ A. Dilmi Bouras, ${ }^{1}$ K. Bouthiba, and ${ }^{2}$ N.E. Assal \\ ${ }^{1}$ Laboratory Nature Bioresources, Faculty of Science, University Hassiba Benbouali - Chlef, Algeria . \\ ${ }^{2}$ Lactamel group, Sidi-Belabes, Algeria.
}

\begin{abstract}
The milk remains a major food supply to the Man and his demand is ever growing. This important application involves high price of a liter of milk and thus an inability of certain non- producer to meet the needs of their peoples countries. Faced with this situation some countries including Algeria must think of now is to find a way to reduce this dependence by substituting cow's milk, in part, by another abundant commodity in the world and cheaper. In this work we extracted milk by grinding soybeans mixed with water and then brought to boiling and filtered. Similarly, we used the soy flour. Soymilk, we extract and then improved by $20 \%$ of cow milk, is a healthy drink liquid, and organoleptic (flavor, color, appearance, odor) and satisfactory nutritional. Similarly, the yogurt obtained by this mixture has a smooth, creamy texture, smooth and with a significant characteristic white color in mammalian milk. Similarly, the nutritional value is very close to that of cow milk yogurt. This milk is as a very interesting alternative.
\end{abstract}

Keywords : Quality, Milk, Yogurt, Soy.

\section{Introduction}

Milk is a major food supply to the Man and his demand is growing. Implying high prices of a liter of milk and thus an inability of certain non- producer to meet the needs of their peoples countries. In Africa, production is 110 liters of milk / cow / year; While in Europe, it is 6,000 liters / cow / year. This difference is partly due to the difficult conditions of milk production in Africa.

Algeria imports more than $70 \%$ availability in milk and milk products (3rd largest importer). Given the low level of milk productivity and to ensure coverage of the growing demand for milk will become more expensive, Algeria must think of now is to find a way to reduce this dependence by substituting milk another abundant commodity in the world and less expensive. We thought soy milk, which can replace milk, even in part, in the manufacture of dairy products.

We set the following objectives:

- Study of various physicochemical and nutritional characteristics of soy milk.

- Test of improving the taste of milk and soya yoghurt.

\section{Materials and Method}

This whole work was made in the laboratory of food biochemistry of the department of biology, Hassiba
Ben Bouali Chlef University and in the laboratory of quality control and the repression of the frauds of Chlef, Algeria.

\subsection{Physicochemical analyzes}

The different physicochemical analysis techniques (dry matter, ash content, $\mathrm{pH}$, titratable acidity, density, fat, sugars, and total nitrogenous matter) used are recommended by conventional assays [1].

\subsection{Sensory analysis}

To improve the taste of soymilk Bjorg we added $20 \%$ of whole cow milk, $1 \%$ sucrose. The organoleptic test is based on the appearance (color, appearance, and texture), smell and taste. An amount of each sample is analyzed as follows:

- Visual Analysis: is to observe and note the color and fluid samples.

- Olfactory analysis: based on the determination of the characteristic odor and flavor nasally.

- Palate: determined by the flavor and acidity.

\subsubsection{Preparation of soy milk}

In addition to the soy milk Bjorg (control), we prepared a sample of other soy milk with $20 \%$ whole milk and $1 \%$ sucrose (Table 1 ).

*Corresponding author: ${ }^{1}$ Laboratory Nature Bioresources , Faculty of Science, University Hassiba Benbouali Chlef, Algeria, Tel: 213 661733890,E-mail: dilmibourasa@ hotmail.com 
Table 1. Different milk samples used

\begin{tabular}{ll}
\hline Sample & Origin \\
\hline Bjorg (control) & soy beverage nature of the brand Bjorg \\
\hline ISM (improved soy milk) & $79 \%$ milk Bjorg $+20 \%$ whole milk $+1 \%$ sucrose \\
\hline
\end{tabular}

\subsubsection{Manufacture of a yoghurt based soymilk}

The milk, after heating at $70{ }^{\circ} \mathrm{C}$ for 5 minutes, is brought to a temperature suitable for sowing: $42^{\circ} \mathrm{C}$. The seeding is done directly by the addition of lactic acid bacteria (Streptococcus thermophilus and Lactobacillus bulgaricus). Two types of products are manufactured: Bjorg yoghurt (control) yoghurt and ISM. he inoculated milk was distributed into sterile jars and incubated in an incubator $\left(42^{\circ} \mathrm{C}\right)$ until the desired acidity of $60^{\circ} \mathrm{D}$, and then cooled to $4{ }^{\circ} \mathrm{C}$.

\section{Results}

\subsection{Physicochemical analysis}

The average values of the results of the physicochemical analyzes of different soy milks are shown in Table 2.

Table 2. Results of the physicochemical analysis of soy milks: Bjorg and ISM.

\begin{tabular}{|c|c|c|c|}
\hline Soy milks & BJORG (control) & ISM & Cow milk* \\
\hline pH & 7.09 & 6.51 & [6.50-6.80] \\
\hline Titratable acidity $\left({ }^{\circ} \mathrm{D}\right)$ & 16.20 & 15.90 & [14-16] \\
\hline $\operatorname{Ash}(\%)$ & 9.56 & 10.37 & [11.0-13.0] \\
\hline Dry matter (\%) & 0.10 & 0.12 & {$[0.08-0.10]$} \\
\hline Sugars $(\%)$ & 1,00 & 2.30 & {$[4.50-5.0]$} \\
\hline Fat $(\%)$ & 3,00 & 3.00 & {$[3.0-3.5]$} \\
\hline Protein $(\%)$ & 3.80 & 4.93 & {$[4.5-5.2]$} \\
\hline Viscosity at $20^{\circ} \mathrm{C}$ & 2.16 & 2.67 & - \\
\hline Density at $20^{\circ} \mathrm{C}$ & 1.01 & 1.050 & 1,032 \\
\hline
\end{tabular}

\subsection{Sensory analysis}

\subsubsection{Soymilks}

After taste test milk Bjorg and ISM, we noted their characteristics and the results are reported in Tab. 3 .

\subsubsection{Yogurt with soy milk}

\subsubsection{Main Features}

Soymilk fermented normally favorable conditions for the development of lactic acid bacteria as indicated Bourgeois and lapent [3]. Due to its improved soymilk (ISM) composition is a good medium for the growth of lactic acid bacteria. The yogurt obtained has a slightly yellowish white color, color characteristic soymilk.

\subsubsection{Acidity of the yogurt}

After titration of $10 \mathrm{ml}$ of soy yogurt with a solution of sodium hydroxide $(0.9 \%)$, in the presence of phenolphthalein, we found that the acidity increases gradually during storage at $4^{\circ} \mathrm{C}$. From an initial acidity of $60^{\circ} \mathrm{D}$ we arrive at $92^{\circ} \mathrm{D}$ after 10 days and $110^{\circ} \mathrm{D}$ after 20 days (Figure 1). 
Table 3. Results of sensory testing of milk Bjorg and ISM

\begin{tabular}{cccccc}
\hline print & Odor & Color & Taste & Acidity & Consistency \\
Ech & & & & & \\
& & & & & \\
\hline BJORG & characteristic & yellowish & bean taste & not acid & just farm \\
ISM & feature-pleasing & matt white & nice - sweet & not acid & just farm \\
& & & & & \\
\hline
\end{tabular}

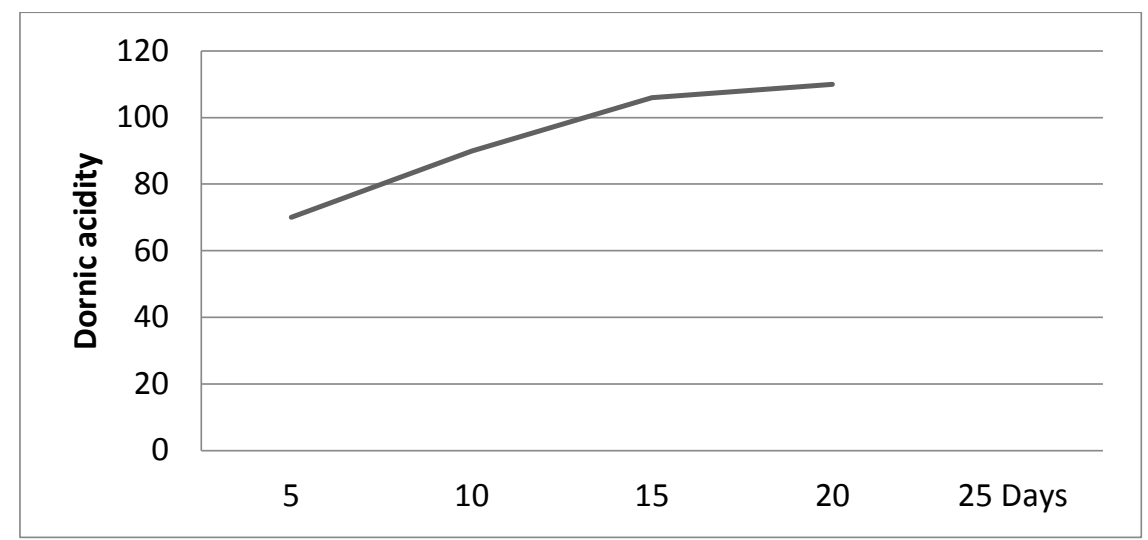

Figure 1: Evolution of the acidity of soy yogurt during storage at $4{ }^{\circ} \mathrm{C}$

\section{Discussion}

\subsection{Physicochemical analysis}

The ISM has a sugar content, protein and solids mater more important than milk Bjorg (Table 1). This difference is due to the additions of milk and sucrose. The ISM has a pH (6.51) and Dornic acidity (15.9) lower than milk Bjorg (respectively 7.09 and 16.2). The acidity of the milk is related to its composition (high content of acidic substances) proteins, phosphate anion, citrate, lactic acid [4].

The $\mathrm{pH}$ results are comparable to those reported by Turatsinze, (2001), which is a pH range of 6.8 to 7.2 for different soymilks. The $\mathrm{pH}$ of the ISM is similar to that of cow's milk (6.7) [2] and goats (6.6) [5].

Despite the additions, the ISM remains with less sugar $(2.30 \%)$ compared to cow's milk (1.0\%). The carbohydrate content of the soy milk is highly dependent on the processing temperature. This difference is probably due to the processing temperatures used and to the duration of maceration [4]. These results can be beneficial for people with lactose intolerance and diabetes.

The average values of the levels solids content of Bjorg milk and ISM are more or less suitable, but still lower than those reported by the literature $[7,2]$ which are respectively: (10 to $11.5 \%)$ and (11-13\%). The difference in the solids content is presumably due to the concentration of milk proteins, fats and sugars.
The fat content of milk Bjorg and ISM are closer than those reported by the literature $[2,8]$ for cow's milk. Concentrations in milk fat Bjorg and ISM are greater than those reported by several authors, including Godon [7] who found that the tonyu a rate of 1.5 to $2.3 \%$ fat, whereas Chen [9] found that the soybean milk containing $2 \%$ fat.

Soy milk has the advantage of containing less saturated fat than cow's milk and be free of trans fatty acids, thus becoming more favorable to people at risk of cardiovascular problems.

The protein content of the ISM $(4.93 \%)$ is higher than that of milk Bjorg $(3.80 \%)$. But equivalent to cow's milk (4.5 and 5.3) [2]. The protein levels ISM is related to the richness of seed proteins.

\subsection{Sensory analysis}

\subsubsection{Soymilks}

The results in Table 3 and for soy milk Bjorg are consistent with those found by Godon [7] and concluded that the taste of bean appears from grinding the raw seed, so from contacting different compounds (enzyme - substrate). Moreover, there on set of a bitter and astringent taste caused by the presence of oxidized phenolic compounds [10]. After improvement of soymilk Bjorg by milk and sucrose, there is loss of taste bean and tasters find almost identical to cow's milk with a sweet flavor. The same applies to the smell; it improved after adding milk and sucrose. 
The color of soy milk Bjorg was yellowish characteristic seeds, changes and becomes yellowish white, after addition of $20 \%$ of cow's milk and $1 \%$ sacharrose. The color of the ISM has taken the milk after addition.

Soy milk is slightly firm. The consistency is due to the quantity of water used during the manufacturing. Furthermore, the ISM is not acid because its $\mathrm{pH}$ near to neutrality (6.51) and the Dornic acidity is $15.9^{\circ}$ D.

\subsubsection{Yogurt with soy milk}

\subsubsection{General characteristics}

The yoghurt obtained has a slightly yellowish white color, color characteristic soymilk. Yogurt with fruit (plums and apricots) has organoleptic characteristics similar to milk yogurt: pleasant smell and loss of aroma characteristics of soy flour. The results found are similar to those found by the literature. The unpleasant odor and flavor of soy flour disappear after fermentation by lactic acid bacteria [3].

The soy milks are used for the production of fermented products like yoghurts. It is at this level change in the manufacturing process because there are no lactose and little carbohydrate generally. In the case of soymilk Lactobacillus bulgaricus is not able to develop. It was necessary to introduce carbohydrates (1\%) and $20 \%$ cow's milk.

The test results show that the taste of yoghurt prepared with $80 \%$ soya milk and $20 \%$ cow's milk has been satisfactory for all volunteers.

\subsubsection{Acidity of the yogurt}

The evolution of the acidity of yogurt ISM, during conservation, develops and reflects the activity of ferments. The titratable acidity increases by the lactic fermentation, it increases with the number of germs and the temperature during the storage time [11]. The acidity of the fermented soybean milk should be $60^{\circ} \mathrm{D}[12]$.

\section{Conclusions}

Characteristics soymilk improved (ISM) are very satisfactory with a pleasant smell, color white-mate and a nice-sweet taste. Yogurt with fruit (plums and apricots) has organoleptic characteristics similar to milk yogurt: pleasant smell and loss of aroma characteristics of soy flour.
Daily consumption of cow's milk and its derivatives should be preferred for their natural wealth calcium. However, the soybean milk is a good alternative to milk; it is enriched in calcium, for the manufacture of soy milk, yoghurt, custard for intolerant of cow's milk (lactose intolerance and intolerance to people's milk proteins). The use of this type of milk and dairy products may reduce the ever increasing pressure on the cow's milk that is going to become less abundant and therefore more expensive.

\section{References}

[1] Gautier JA, Renault J. Fiche technique d'analyse bromatologique. Société d'édition d'enseignement supérieur, Paris 1961 ; pp 122-200.

[2] Schmack P, Pfundreiser G. Studium über die Wohltaten von Ziegenmilch, ALP, Berlin, 2010.

[3] Bourgeois CM, Larpent JP. Microbiologie alimentaire. Aliments fermentés et fermentation alimentaire. Ed: Tec et Doc.; 1996. P : 233-246.

[4] Gerard D. Lait nutrition et santé. Edition : tec et doc, isb., 20018 ; 41-557.

[5] FAO. Le lait et les produits laitiers dans la nutrition humaine. Chap.5 : laits fermentés, collection FAO/Alimentation et nutrition, 2002. (28) :7.

[6] Apfelbaum M, Romon M et Dupus M. (6e édition), Diététique et nutrition. Paris, Masson; 2004.

[7] Godon B. Protéines végétales. $2^{\mathrm{eme}} \mathrm{Ed:}$ Tec et Doc. Lavoisier. 1996, Paris, 367-408.

[8] Courtet-Leymarios F. Qualité nutritionnelle du lait de vache et ses acides gras. Voies d'amélioration par l'alimentation. Thèse de Doctorat vétérinaire. Faculté de médecine de Créteil. 2010 ; 113 p.

[9] Chen S. Preparation of fluid soymilk. Proceedings of the world congress on vegetable protein utilization in human foods and animal feedstuffs, 2-7/10/1988, Signapore. Am Oil Chem Soc, Champaign, Illinois, USA, 1988. 341-352.

[10] Arai S, Suzuki H, Fujimaki M, Sakurai Y. Studies on flavor components in soybean. Part 2. Phenolic acids in defatted soybean flour. Agric Biol Chem 1966; 30:263.

[11] Carol D, Vignola A. Science et technologie du lait. Edition : presse internationale, polytechnique. $2002 ; 28,34-571$.

[12] Jean PL. Microbiologie alimentaire technique de laboratoire. Ed: lavoisier, Tec et Doc. 1997 ; P 929-934. 